\title{
Influence of low-level laser therapy on vertical jump in sedentary individuals
}

\author{
Influência do laser de baixa potência no salto vertical em indivíduos sedentários
}

\author{
Camila Mayumi Martin Kakihata ${ }^{1}$, Jéssica Aline Malanotte ${ }^{1}$, Jessica Yumie Higa ${ }^{1}$, Tatiane Kamada Errero ${ }^{1}$, \\ Sandra Lucinei Balbo ${ }^{1}$, Gladson Ricardo Flor Bertolini ${ }^{1}$
}

\begin{abstract}
Objective: To investigate the effects of low intensity laser (660nm), on the surae triceps muscle fatigue and power, during vertical jump in sedentary individuals, in addition to delayed onset muscle soreness. Methods: We included 22 sedentary volunteers in the study, who were divided into three groups: $\mathrm{G} 1(\mathrm{n}=8)$ without performing low intensity laser (control); G2 ( $n=7)$ subjected to 6 days of low intensity laser applications; and $G 3(n=7)$ subjected to 10 days of low intensity laser applications. All subjects were evaluated by means of six evaluations of vertical jumps lasting 60 seconds each. In G2 and G3, laser applications in eight points, uniformly distributed directly to the skin in the region of the triceps surae were performed. Another variable analyzed was the delayed onset muscle soreness using the Visual Analog Scale of Pain. Results: There was no significant difference in fatigue and mechanical power. In the evaluation of delayed onset muscle soreness, there was significant difference, being the first evaluation higher than the others. Conclusion: The low intensity laser on the triceps surae, in sedentary individuals, had no significant effects on the variables evaluated.
\end{abstract}

Keywords: Laser therapy, low-level; Muscle fatigue; Fatigue; Myalgia; Sedentary lifestyle

\section{RESUMO}

Objetivo: Verificar os efeitos do laser de baixa potência (660nm) sobre 0 tríceps sural na fadiga muscular e na potência, durante 0 salto vertical, em indivíduos sedentários, além da dor muscular de início tardio. Métodos: Foram inclusos no estudo 22 voluntários sedentários, divididos em três grupos: $\mathrm{G} 1(\mathrm{n}=8)$, sem realização de laser de baixa potência (controle); G2 ( $n=7)$, submetido a 6 dias de aplicações de laser de baixa potência; e $\mathrm{G} 3(\mathrm{n}=7)$, submetido a 10 dias de aplicações de laser de baixa potência. Todos os indivíduos foram avaliados por meio de seis avaliações de saltos verticais, com duração de 60 segundos cada. No G2 e G3, foram realizadas aplicações de laser em oito pontos, distribuídos uniformemente e diretamente na pele, na região de do tríceps sural. Outra variável analisada foi a dor muscular de início tardia, utilizando a Escala Visual Analógica de Dor. Resultados: Não houve diferença significativa na fadiga e na potência mecânica. Na avaliação da dor muscular tardia, houve diferença significativa, sendo a primeira avaliação maior do que as demais avaliações. Conclusão: A aplicação do laser de baixa potência no tríceps sural, em indivíduos sedentários, não apresentou efeitos significativos nas variáveis avaliadas.

Descritores: Terapia a laser de baixa intensidade; Fadiga muscular; Fadiga; Mialgia; Estilo de vida sedentário

\section{INTRODUCTION}

During vigorous exercise the muscles commonly present progressive decline in performance and power that commonly recover after a period of resting. This reversible phenomenon generally described as muscle fatigue works as a defense process of the organism in the attempt to avoid that the body energy reserves run out. ${ }^{(1-3)}$

Muscle fatigue is developed after repetitive contractions and it is associated with type and intensity of exercise, muscles groups involved, biochemical substrate and accumulation of metabolite. In addition, muscle fatigue also decrease the adenosine triphosphate (ATP) sources, such as muscle glycogenic and phosphocreatine..$^{(1)}$

\footnotetext{
'Universidade Estadual do Oeste do Paraná, Cascavel, PR, Brazil.

Corresponding author: Gladson Ricardo Flor Bertolini - Rua Universitária, 2.069 - Jardim Universitário - Zip code: 85819-110 - Cascavel, PR, Brazil - Phone: (55 45) 3220-3157 - E-mail: gladsonricardo@gmail.com Received on: July 31, 2014 - Accepted on: Jan 10, 2015

Conflict of interest: none.

DOI: 10.1590/\$1679-45082015A03243
} 
Such fatigue can occur in some movements during practice of sports such as vertical jump that is characterized by a dynamic and complex movement involving different motor activations that result in rapid eccentric muscle action followed by maximal concentric contraction. ${ }^{(4)}$ Such movement is also used as one of the best forms to evaluate levels of muscle mechanical power (MP) ${ }^{(5)}$ harming directly by the fatigue that can be measured by fatigue index obtained in continuous vertical jump test for 60 seconds. ${ }^{(6)}$

One possible forms to prevent fatigue and improve recovery of skeletal muscle is using the low-power laser irradiation (LPLI) because of the physiological and therapeutic effects provided as the increase of cellular metabolism that wider synthesis of protein such as ATP, RNA and mainly the function of mitochondrial structure. ${ }^{(7)}$ This structural adaptation eventually result in the ability to provide higher levels of breathing and energy (ATP) for cells, which characterizes an metabolic adaptation. $^{(8)}$

Several investigations exist on the effect of LPLI in cellular metabolism, however, its application in the improvement of muscle performance is still little investigated. There are studies that aim to evaluate electromyographic fatigue ${ }^{(9,10)}$ and gain of strength, ${ }^{(11)}$ but no studies were found evaluating the pure result of LPLI on the functional activity, such the jump, evaluated using jump platforms.

\section{OBJECTIVE}

To determine effects of low-power laser (660nm), on triceps surae during vertical jump exercise in sedentary individuals; evaluate muscle power during 1 minute and in four specific "phases" of 15 minutes; and analyze the fatigue index and delayed onset muscle soreness.

\section{METHODS}

This experimental cross-sectional study included a purposive sample and was conducted at Universidade Estadudal do Oeste do Paraná (UNIOESTE), Cascavel campus. The University Comitê de Ética em Pesquisa [Ethics and Research Committee] approved the study, protocol number 056/2013, CAAE: 15570413.1.0000.0107.

We included volunteers who did not exercise regularly for 6 months before participation, did not used medicines and/or nutritional supplements and did not have any muscle, bone or joint injury in lower limbs, and even disease of cardiovascular and/or systemic system. Participants who had reported discomfort during tests and/or were absent in the day of the test were excluded.

\section{Sample group}

A total of 36 volunteers from UNIOESTE were evaluated. Of them, 22 were included (16 were women). Participants were aged 21.27 \pm 2.8 years (21.5, IQ, 21-28). Reasons of exclusion were practice of exercise and recent musculoskeletal disorders.

Antropometrical characteristics of volunteers in mean values were height $1.68 \pm 0.10 \mathrm{~m}$ (1.65, IQ, 1.64-1.80), weight $64.59 \pm 13.97 \mathrm{~kg}(64, \mathrm{IQ}, 53-75)$ and body mass index $22.51 \pm 3.57 \mathrm{~kg} / \mathrm{m}^{2} \quad(23,44$, IQ, 19,70-23,14). Participants signed the consent form and were informed that evaluations will be done at UNIOESTE in a pre-scheduled day and time convenient to each individual. Sample was randomly divided into three groups: $\mathrm{G} 1(\mathrm{n}=8)$ without LPLI application (control group); G2 $(n=7)$, submitted to 6 days of LPLI application; G3 $(n=7)$ submitted to 10 days of LPLI application.

We observed that seven individuals from each group had differences to be detecting of $7.5 \mathrm{~W} . \mathrm{kg}-1$, with standard deviation of 5.5. In addition, presented test power of $80 \%$ with significance level of $5 \%$. All volunteers were evaluated during jumps in 5 different days. The first evaluation always occurred in the beginning of the week.

\section{Jump protocol}

The jump test of 60 seconds ${ }^{(12,13)}$ constitutes of maximal vertical jumps of Counter Movement Jump type during execution on a force plate measuring $50 \times 66 \mathrm{~cm}$, connected to MultiSprint Full (software Multisprint) that provide flying time and force of each jump as well number of jumps.

In the 1st day, individuals were guided on how to jump and they did as following: the volunteer was positioned on the force plate with hands on waist and looking toward a fixed point in the his/her eye level and they were asked to begin jumping with bending knee roughly $110^{\circ}$. The movement was interrupted repeated for 60 seconds with maximal power as possible. Individuals were guided to keep trunk in the vertical and extensive knee during flying. All volunteer jumped without shoes to not influence result because of differences among shoes. During the jump, participants were followed by two observers, one responsible for verbal incentive and other to register data - both blind in relation to each group the volunteer belonged. In all evaluations (EV), both observers were presented. 
All groups performed jump tests in the same days and the protocol was different only in the 1 st and in the last day of the intervention. In the 1st day jumps (EV1) were followed by 5 minutes of resting and LPLI was applied in groups G2 and G3. Posteriorly, all participants jumped again (EV2). In that day, they did two jumps to verify some immediate effect in LPLI application.

Following evaluations occurred in 50 (EV3), 8o (EV4), $12^{\mathrm{o}}$ (EV5), which occurred in the LPLI application before the jump of groups G2 and G3. The group G1 only jump was done. In the last day of evaluation, concerning the 150 day (EV6), there was only jump independently of the group (Chart 1).

Chart 1. Protocol chronogram of low-power laser and vertical jump

\begin{tabular}{|lcccccc|}
\hline Day & Monday & Tuesday & Wednesday & Thursday & Friday & $\begin{array}{c}\text { Saturday } \\
\text { and Sunday }\end{array}$ \\
& $\mathbf{1}$ & $\mathbf{2}$ & $\mathbf{3}$ & $\mathbf{4}$ & $\mathbf{5}$ & $\mathbf{6} \mathbf{e} \mathbf{7}$ \\
\hline G1 & CVJ-CVJ & - & - & - & CVJ & - \\
G2 & CVJ-LPLI-CVJ & - & LPLI & - & LPLI-CVJ & - \\
G3 & CVJ-LPLI-CVJ & LPLI & LPLI & LPLI & LPLI-CVJ & - \\
\hline Day & $\mathbf{8}$ & $\mathbf{9}$ & $\mathbf{1 0}$ & $\mathbf{1 1}$ & $\mathbf{1 2}$ & $\mathbf{1 3}$ e 14 \\
\hline G1 & CVJ & - & - & - & CVJ & - \\
G2 & LPLI-CVJ & - & $L P L I$ & - & LPLI-CVJ & - \\
G3 & LPLI-CVJ & LPLI & LPLI & LPLI & LPLI-CVJ & - \\
\hline Day & $\mathbf{1 5}$ & & & & & \\
\hline G1 & CVJ & & & & &
\end{tabular}

CVJ: Countermovement Vertical jump; LPLI: low-power laser irradiation; G: group.

MP is showed in W.kg-1 and obtained using the following equation:

$$
\mathrm{MP}=\mathrm{g}^{2} . \mathrm{Tf} .60 /[4(\mathrm{n}) .(60 . \mathrm{Tf})]
$$

The letter "g" means the gravity acceleration (9.81m.s-2), "Tf" that is the sum of flying time of all jumps and " $n$ " the number of jumps done during the period lasting for 60 seconds.

In addition, MP was also calculated for each phase of 15 seconds, from tests of 60 seconds, adequate entrances of equation for each phase, concerning number of jumps related with number of jumps and duration of evaluation period (from 60 seconds to 15 seconds). ${ }^{(12)}$ The MP of five phases was obtained as following: general phase ( 0 to 60 seconds), $1^{\circ}$ phase $(0$ to 15 seconds), $2^{\mathrm{o}}$ phase (16 to 30 seconds), $3^{\circ}$ phase (31 to 45 seconds) and $4^{\circ}$ phase ( 46 to 60 seconds).

Fatigue index was estimated between MP peak, corresponding to mean power developed within first 15 seconds and mean power of the last 15 seconds of the test as proposed by Hespanho et al. ${ }^{(6)}$ The fatigue index was expressed in percentages by three simple rules.

\section{Protocol for application of low-power laser}

The volunteer remained in ventral decubitus position in order to surae triceps region be discover. Firstly, the local asepsis was done and application and, next, the laser was irradiated in $90^{\circ}$ angle with tissue, mild pressure and point form (eight points, distributed uniformly) as described in figure 1 . The application occurred from proximal to distal and from lateral to medial. Irradiation parameters were long wavelength $(660 \mathrm{~nm})$; existing power $\left(30 \mathrm{~mW} 0\right.$; spot area $\left(0.06 \mathrm{~cm}^{2}\right)$; power density $\left(0.5 \mathrm{~W} / \mathrm{cm}^{2}\right)$; irradiated energy by point $(0.24 \mathrm{~J})$; energy density $\left(4 \mathrm{~J} / \mathrm{cm}^{2}\right)$; irradiation time $(8$ seconds); amount of irradiated points (eight points); and energy of irradiated total (1.92J).

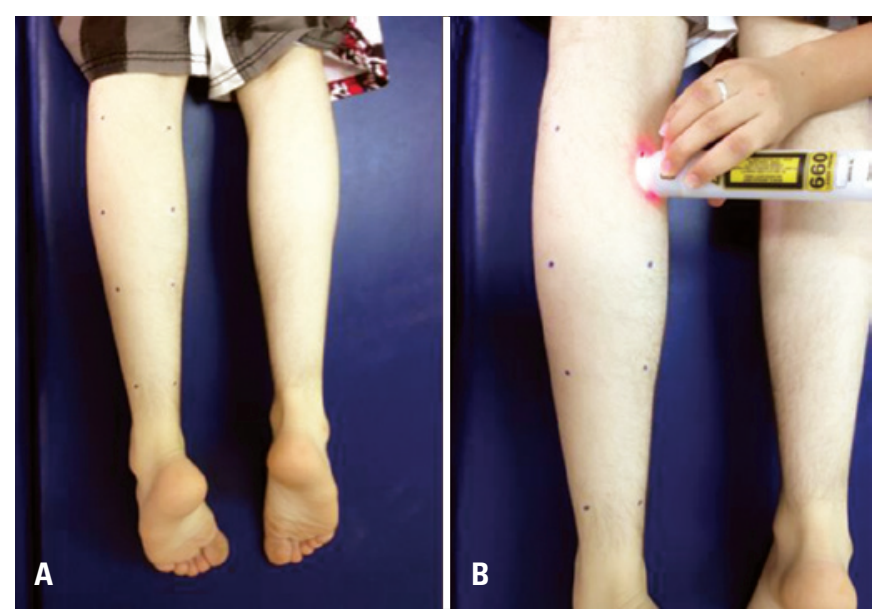

Figure 1. (A) Points marked for low-frequency laser. (B) Demonstration of lowfrequency laser application

\section{Evaluation of delayed onset muscle soreness}

To evaluate pain we used visual analogue scale that comprises in a horizontal line of $10 \mathrm{~cm}$ in length, nonnumbered, anchored by word descriptors at each end ("no pain" and "worst pain ever imagined"). To complete this scale the volunteer were questioned concerning pain intensity the day after the jump. A total 
of 5 evaluations were done in relation to 72 hours of exercises and after each day after the day of the jump.

\section{Statistical analysis}

We used the statistical package for social Science (SPSS), 15 version, for statistical analyses, and for comparison the mixed design of variance analysis (ANOVA) with Bonferroni post-test, considering $\alpha=0.05$.

\section{RESULTS}

According to the analysis among groups and evaluations, no significant difference was seen among fatigue variables
$[\mathrm{F}(3.1 ; 58.7)=1.30 ; \mathrm{p}=0.282]$, and $\mathrm{MP}$ in the general phase $[\mathrm{F}(6.2 ; 60)=1.83 ; \mathrm{p}=0.106]$ (Table 1$)$.

No difference was seen in the power analysis at four phases among groups and evaluations. Results were the following at first phase $\mathrm{F}(3.3 ; 63.1)=0.091$ $(p=0.973)$, second phase $F(3.3 ; 63.7)=1.02 \quad(p=0.394)$, third phase $\mathrm{F}(2.7 ; 51.6)=0.504(\mathrm{p}=0.663)$ and fourth phase $\mathrm{F}(7.6 ; 59.1)=0.840(\mathrm{p}=0.481)($ Table 2$)$.

The evaluation of delayed onset muscle soreness showed a significant difference $[\mathrm{F}(1.6 ; 31.5)=89.59$; $\mathrm{p}<0.001]$ among EV1, EV2 up to EV5. EV1 showed high score than other evaluations. However, in comparison among groups no significant difference was found (Table 3).

Table 1. Result of evaluations of fatigue and general phase power

\begin{tabular}{|c|c|c|c|c|c|c|c|}
\hline & & EV1 & EV2 & EV3 & EV4 & EV5 & EV6 \\
\hline \multirow[t]{3}{*}{ Fatigue } & G1 & $8.665 \pm 4.68$ & $9.922 \pm 6.11$ & $10.88 \pm 6.31$ & $7.768 \pm 3.00$ & $8.487 \pm 2.95$ & $8.432 \pm 2.32$ \\
\hline & $\mathrm{G} 2$ & $14.02 \pm 6.70$ & $14.69 \pm 5.79$ & $15.43 \pm 9.94$ & $14.63 \pm 8.05$ & $14.63 \pm 8.97$ & $14.97 \pm 8.11$ \\
\hline & G3 & $9.696 \pm 3.91$ & $9.928 \pm 3.79$ & $10.05 \pm 3.00$ & $11.25 \pm 3.52$ & $9.875 \pm 1.94$ & $10.05 \pm 2.76$ \\
\hline \multirow[t]{3}{*}{ General phase power } & G1 & $12.98 \pm 4.80$ & $14.24 \pm 5.80$ & $12.86 \pm 6.95$ & $10.61 \pm 3.75$ & $10.81 \pm 3.85$ & $10.23 \pm 3.13$ \\
\hline & $\mathrm{G} 2$ & $15.70 \pm 5.40$ & $16.46 \pm 5.96$ & $16.73 \pm 7.80$ & $16.58 \pm 6.96$ & $16.39 \pm 8.07$ & $17.26 \pm 7.56$ \\
\hline & G3 & $13.22 \pm 5.10$ & $12.15 \pm 5.09$ & $13.01 \pm 3.69$ & $13.00 \pm 4.06$ & $13.01 \pm 3.18$ & $13.18 \pm 3.35$ \\
\hline
\end{tabular}

G: group; EV: evaluations

Table 2. First phase evaluation of power phase

\begin{tabular}{|c|c|c|c|c|c|c|c|}
\hline & & EV1 & EV2 & EV3 & EV4 & EV5 & EV6 \\
\hline \multirow[t]{3}{*}{ 10 phase } & G1 & $14.82 \pm 4.88$ & $15.78 \pm 5.22$ & $14.79 \pm 7.15$ & $14.26 \pm 6.00$ & $13.42 \pm 5.81$ & $12.49 \pm 4.95$ \\
\hline & G2 & $19.12 \pm 5.79$ & $19.80 \pm 6.29$ & $19.11 \pm 6.05$ & $19.59 \pm 6.77$ & $19.18 \pm 8.10$ & $20.47 \pm 7.04$ \\
\hline & G3 & $15.72 \pm 6.07$ & $14.23 \pm 6.01$ & $15.89 \pm 5.55$ & $15.52 \pm 5.73$ & $15.93 \pm 4.69$ & $16.66 \pm 4.95$ \\
\hline \multirow[t]{3}{*}{$2^{\circ}$ phase } & G1 & $13.57 \pm 5.92$ & $14.80 \pm 7.17$ & $14.47 \pm 8.74$ & $11.79 \pm 4.34$ & $11.97 \pm 4.80$ & $10.74 \pm 3.49$ \\
\hline & $\mathrm{G} 2$ & $16.65 \pm 4.54$ & $17.66 \pm 5.60$ & $18.09 \pm 8.21$ & $17.43 \pm 6.44$ & $17.12 \pm 7.49$ & $18.39 \pm 7.43$ \\
\hline & G3 & $14.99 \pm 5.17$ & $13.68 \pm 6.24$ & $15.33 \pm 5.37$ & $13.99 \pm 5.01$ & $14.59 \pm 4.09$ & $14.54 \pm 3.85$ \\
\hline \multirow[t]{3}{*}{$3^{\circ}$ phase } & G1 & $12.22 \pm 7.28$ & $12.34 \pm 7.27$ & $11.94 \pm 6.94$ & $10.05 \pm 3.86$ & $9.93 \pm 3.55$ & $9.78 \pm 2.99$ \\
\hline & $\mathrm{G} 2$ & $15.41 \pm 6.36$ & $15.55 \pm 5.55$ & $16.97 \pm 9.34$ & $16.37 \pm 7.59$ & $15.65 \pm 8.22$ & $16.68 \pm 7.56$ \\
\hline & G3 & $13.40 \pm 6.15$ & $11.46 \pm 5.35$ & $12.13 \pm 2.98$ & $12.40 \pm 3.67$ & $12.50 \pm 2.90$ & $12.31 \pm 2.96$ \\
\hline \multirow[t]{3}{*}{$4^{\circ}$ phase } & G1 & $8.66 \pm 4.68$ & $9.92 \pm 6.11$ & $10.88 \pm 6.31$ & $7.76 \pm 3.00$ & $8.48 \pm 2.95$ & $8.43 \pm 2.32$ \\
\hline & $\mathrm{G} 2$ & $14.02 \pm 6.70$ & $14.69 \pm 5.79$ & $15.43 \pm 9.94$ & $15.00 \pm 8.05$ & $14.63 \pm 8.97$ & $14.97 \pm 8.11$ \\
\hline & G3 & $9.69 \pm 3.91$ & $9.92 \pm 3.79$ & $10.05 \pm 3.00$ & $11.25 \pm 3.52$ & $9.87 \pm 1.94$ & $10.05 \pm 2.76$ \\
\hline
\end{tabular}

G: group; EV: evaluations.

Table 3. Result of evaluations of delayed onset muscle soreness

\begin{tabular}{lccccc}
\hline Groups & EV1 & EV2* & EV3* & EV4* $^{*}$ & \\
\hline G1 & $6.8 \pm 2.2$ & $0.3 \pm 0.7$ & $0.1 \pm 0.4$ & 0 \\
G2 & $4.7 \pm 2.6$ & $1 \pm 1.7$ & $0.1 \pm 0.4$ & 0 \\
G3 & $5.1 \pm 2$ & $0.1 \pm 0.4$ & $0.4 \pm 1.1$ & 0 & $0.4 \pm 1.1$ \\
\hline
\end{tabular}

* Significant difference comparing with EV1; G: group; EV: evaluations. 


\section{DISCUSSION}

The LPLI therapy to prevent muscle fatigue has been recently investigated. However, biological mechanism that fundament the positive results seen in clinical studies still unclear, leading us to believe that such findings are because of the laser effects on oxidative stress, mitochondrial activity and microcirculation. ${ }^{(14)}$

Our study evaluated the pure action of LPLI based on variable of an active commonly done during practice of sports. There were not significant immediate and late effects in muscle fatigue during vertical jump. Similar result concerning fatigue was observed by Leal Jr. et al., ${ }^{(14)}$ who suggested that the result occurred because of the use of long wavelength red laser that has low penetration in the skin compared with infrared that can lead lower amount of energy provided to the tissue, causing effects only in the peak torque of first contractions. Vieira et al. ${ }^{(8)}$ also used cluster of $808 \mathrm{~nm}$ with total energy of $18 \mathrm{~J}$ (by limb), during 9 weeks after with cycle ergometer, observed protective effect of laser with muscle fatigue.

By using cluster therapy with diodes emission within length of red wave $(660 \mathrm{~nm})$ and also infrared $(850 \mathrm{~nm})$ on three points of quadriceps and total dose of 125 , $1 \mathrm{~J}$, Baroni et al. ${ }^{(15)}$ evaluated the muscle fatigue by the torque in isokinetic dynamometer. These authors observed low decrease of torque after fatigue test. By the use of cluster $808 \mathrm{~nm}$ (50.4J of total energy), Ferraresi et al. ${ }^{(16)}$ verified gain of strength associated to an active training was higher than the gain obtained only with strength training. Leal Jr. et al., ${ }^{(1)}$ using infrared cluster multi diode $(810 \mathrm{~nm}, 60 \mathrm{~J}$ of total energy) on two points in brachial biceps of athletes in which fatigue was induced by flexion and extension movements of the elbow observed significant difference in the decrease of fatigue and also improve in muscle performance. Authors suggest that result was achieved by the use of multi diode laser that is able to irradiate several points at the same time, summing a large area of irradiation. In our study, we used laser with only one diode in eight points in a relatively larger muscle single group.

The use of laser for the lack of positive effects and also the low dose energy applied in the study of only 1.92J by limb. Such fact possible explains the absence of improving in results both for fatigue and power in large irradiated areas. Toma et al., ${ }^{(9)}$ evaluated LPLI $(808 \mathrm{~nm}, 10 \mathrm{~mW}, 7 \mathrm{~J})$ in femoral rectus, immediately after the protocol fatigue of the skeletal muscle in elderly women. They did not observe changes in electromyographic fatigue, however, the number of exercises repetitions of plexus-extension achieved by the LPLI group was higher. On the other hand, Kelencz et al., ${ }^{(10)}$ using LED (630nm, with 40nm band), in a study with healthy volunteers who received radiation in eight points of right masseter $(1.044 \mathrm{~J}, 2.088 \mathrm{~J}$ or $3.132 \mathrm{~J}$ by point), obtained increase in muscle activity $(1.044 \mathrm{~J}$ by point) and increase in timing before fatigue $(2.088 \mathrm{~J}$ by point), without changes in contraction power. For this reason, a relationship dose-dependent is suggested in this type of non-coherent irradiation in the red region about the muscle fatigue process.

In addition, to the muscle power variable in all evaluated forms, no significant effects of LPLI were observed. Strength training improves the anaerobic power by the better synchronizing in recruit of muscle fibers. ${ }^{(6)}$ Hence, we believe that different results can be found if strength training is associated with LPLI. This relationship has been already reported by Vieira et al. ${ }^{(8)}$ and Ferraresi et al. ${ }^{(16)}$ both whom applied laser after resistance training, which showed an improve in muscle performance.

In relation to delayed onset muscle soreness, because of pain was high after the first day of jump and after evaluation an decline is seen. Foschini et al. ${ }^{(17)}$ justified such fact as the stress generated by exercise in the organism and remain of stimulus considering that the body tends to generate adaptations in its structure and function, so that, the pain might decrease. Groups with LPLI also did not present differences in the control group, i.e., it does not positively interfere in delayed onset muscle soreness as stated by Craig et al. ${ }^{(18,19)}$ However, Liu et al. ${ }^{(20)}$ observed positive effects of $\mathrm{HeNe}$ laser therapy in rats submitted to eccentric contraction of gastrocnemius model injury with inhibition of inflammatory process, but using only high doses $\left(43 \mathrm{~J} / \mathrm{cm}^{2}\right)$. In addition, Douris et al. ${ }^{(21)}$ in a protocol delayed onset muscle soreness production for brachial biceps showed analgesic effects of therapy with $8 \mathrm{~J} / \mathrm{cm}^{2}$, but the equipment used was cluster with diodes emission within red $(660 \mathrm{~nm})$ and infrared $(880 \mathrm{~nm})$.

Limitations of this study was the lack of adaptation period to exercise, i.e., a period for volunteers to become familiar with movement of jump; and also the fact of grouping in an exercise protocol several muscles, but apply LPLI only in the muscle group. According our results and based on the literature review, no consensus exists in relation to ideal parameters of LPLI application to decrease or delay fatigue, and improve the muscle power. Such finding corroborate results reported by Oliveira et al., ${ }^{(22)}$ which was considered by them the highest challenge for researches.

In addition few studies have analyzed so far the amount of sessions need for LPLI to become efficient against muscle power fatigue. For this reason, it is 
suggested that more studies are need to compared the efficacy of different wavelengths and analyze the area and time of LPLI irradiation, including the instruments such as electromyography for muscle analysis. ${ }^{(23,24}$

\section{CONCLUSION}

In the study about triceps surae muscle in sedentary individuals, the low-power laser $(660 \mathrm{~nm})$ and parameters defined for application did not show efficiency in relation to fatigue nor muscle power during vertical jumps. In addition, no improve in delayed onset muscle soreness was observed.

\section{REFERENCES}

1. Leal Junior EC, Lopes-Martins RA, Frigo L, De Marchi T, Rossi RP, Godoi V, et al. Effects of low-level laser therapy (LLLT) in the development of exerciseinduced skeletal muscle fatigue and changes in biochemical markers related to postexercise recovery. J Orthop Sports Phys Ther. 2010;40(8):524-32.

2. Ascensão A, Magalhães J, Oliveira J, Duarte J, Soares J. Fisiologia da fadiga muscular. Delimitação conceptual, modelos de estudo e mecanismos de fadiga de origem central e periférica. Rev Port Cien Desp. 2003;3(1):108-23.

3. Matos CC, Castro FA. Fadiga: alterações fisiológicas e modelos conceituais. Rev Bras Ciênc Saúde. 2013;11(37):53-61.

4. Marchetti PH, Uchida MC. Influência da fadiga unilateral de membro inferior sobre 0 salto vertical bilateral. Rev Bras Med Esporte. 2011;17(6):405-8.

5. Dal Pupo J, Detanico D, Santos SG. Parâmetros cinéticos determinantes do desempenho nos saltos verticais. Rev Bras Cineantropom Desempenho Hum. 2012;14(1):41-51

6. Hespanhol JE, Silva Neto LG, Arruda M, Dini CA. Avaliação da resistência de força explosiva em voleibolistas através de testes de saltos verticais. Rev Bras Med Esporte. 2007;13(3):181-4.

7. Manteifel V, Bakeeva L, Karu T. Ultrastructural changes in chondriome of human lymphocytes after irradiation with He-Ne laser: appearance of giant mitochondria. J Photochem Photobiol B. 1997;38(1):25-30.

8. Vieira WH, Ferraresi C, Perez SE, Baldissera V, Parizotto NA. Effects of lowlevel laser therapy $(808 \mathrm{~nm})$ on isokinetic muscle performance of young women submitted to endurance training: a randomized controlled clinical trial. Lasers Med Sci. 2012;27(2):497-504.

9. Toma RL, Tucci HT, Antunes HK, Pedroni CR, de Oliveira AS, Buck I, et al. Effect of $808 \mathrm{~nm}$ low-level laser therapy in exercise-induced skeletal muscle fatigue in elderly women. Lasers Med Sci. 2013;28(5):1375-82.
10. Kelencz CA, Muñoz IS, Amorim CF, Nicolau RA. Effect of low-power galliumaluminum-arsenium noncoherent light $(640 \mathrm{~nm})$ on muscle activity: a clinical study. Photomed Laser Surg. 2010;28(5):647-52.

11. Ferraresi C, Hamblin MR, Parizotto NA. Low-level laser (light) therapy (LLLT) on muscle tissue: performance, fatigue and repair benefited by the power of light. Photonics Lasers Med. 2012;1(4):267-86.

12. Bosco C, Komi PV, Tihanyi J, Fekete G, Apor P. Mechanical power test and fiber composition of human leg extensor muscles. Eur J Appl Physiol Occup Physiol. 1983;51(9623):129-35.

13. Storniolo Junior JL, Fischer G, Peyré-Tartaruga LA. Comparação entre dois métodos para determinação de potência mecânica em saltos verticais. Rev Educ Fis/UEM. 2012;23(2):261-70.

14. Leal Junior EC, Nassar FR, Tomazoni SS, Bjordal JM, Lopes-Martins RA. A laserterapia de baixa potência melhora o desempenho muscular mensurado por dinamometria isocinética em humanos. Fisioter Pesqui. 2010;17(4):317-21.

15. Baroni BM, Leal Junior EC, Geremia JM, Diefenthaeler F, Vaz MA. Effect of light-emitting diodes therapy (LEDT) on knee extensor muscle fatigue. Photomed Laser Surg. 2010;28(5):653-8.

16. Ferraresi $C$, de Brito Oliveira $T$, de Oliveira Zafalon L, Menezes Reiff RB, Baldissera V, de Andrade Perez SE, et al. Effects of low level laser therapy (808 nm) on physical strength in humans. Lasers Med Sci. 2011;26(3):349-58.

17. Foschini D, Prestes J, Charro MA. Relação entre exercício físico, dano muscular e dor muscular de início tardio. Rev Bras Cineantropom Desempenho Hum. 2007;9(1):101-6.

18. Craig JA, Barron J, Walsh DM, Baxter GD. Lack of effect of combined low intensitylaser therapy/phototherapy (CLILT) on delayed onset muscle soreness in humans. Lasers Surg Med. 1999;24(3):223-30. Erratum in: Lasers Surg Med. 1999;25(1):88

19. Craig JA, Barlas P, Baxter GD, Walsh DM, Allen JM. Delayed-onset muscle soreness: lack of effect of combined phototherapy/low-intensity laser therapy at low pulse repetition rates. J Clin Laser Med Surg. 1996;14(6):375-80.

20. Liu XG, Zhou YJ, Liu TC, Yuan JO. Effects of low-level laser irradiation on rat skeletal muscle injury after eccentric exercise. Photomed Laser Surg. 2009; 27(6):863-9.

21. Douris P, Southard V, Ferrigi R, Grauer J, Katz D, Nascimento C, et al. Effect of phototherapy on delayed onset muscle soreness. Photomed Laser Surg. 2006;24(3):377-82

22. Oliveira FB, Rocha GG, Silva Neto LS, Matheus JP, Martins EF. Laser terapêutico de baixa intensidade na otimização e performance do movimento humano. Acta Bras Mov Hum. 2014;4(1):52-60.

23. Mohseni Bandpei MA, Rahmani N, Majdoleslam B, Abdollahi I, Ali SS, Ahmad A. Reliability of surface electromyography in the assessment of paraspinal muscle fatigue: an updated systematic review. J Manipulative Physiol Ther. 2014;37(7):510-21.

24. Bartuzi P, Roman-Liu D. Assessment of muscle load and fatigue with the usage of frequency and time-frequency analysis of the EMG signal. Acta Bioeng Biomech. 2014;16(2):31-9. 